\title{
IMPROVEMENT OF SMART PARKING BARRIER AUTONOMY USING BATTERY SUPPLY
}

\author{
Milos Stanojevic, Mladen Babic, Aleksandar Vekic, \\ Laslo Tarjan \& Srdjan Tegeltija
}
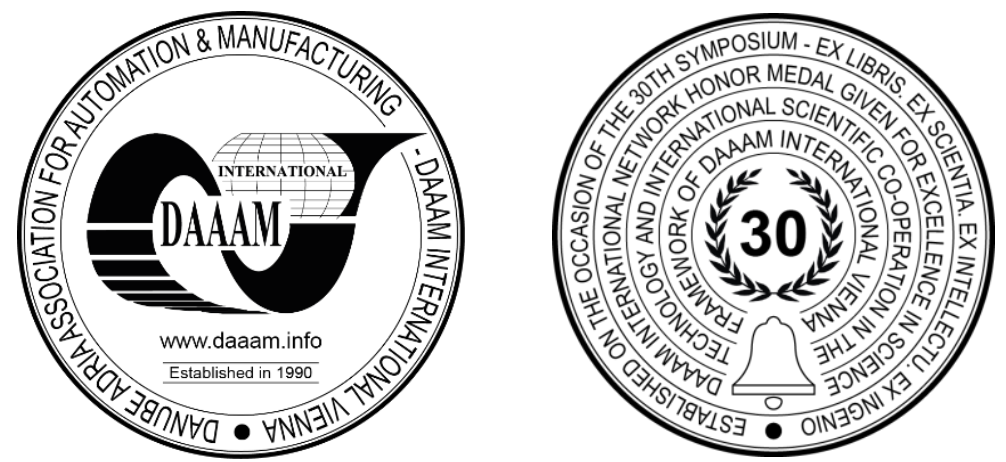

This Publication has to be referred as: Stanojevic, M[ilos]; Babic, M[laden]; Vekic, A[leksandar]; Laslo, T[arjan] \& Tegeltija, S[rdjan] (2019). Improvement of Smart Parking Barrier Autonomy Using Battery Supply, Proceedings of the 30th DAAAM International Symposium, pp.1084-1090, B. Katalinic (Ed.), Published by DAAAM International, ISBN 978-3-902734-22-8, ISSN 1726-9679, Vienna, Austria

DOI: $10.2507 / 30$ th.daaam.proceedings.151

\begin{abstract}
This paper gives one of the smart solutions to the problem that is nowadays becoming more significant and that is the problem of vehicle parking, especially in densely populated areas. As part of the solution to the previous problem is the explanation given in this paper on how the smart parking barrier works and how it is being used. In addition, smart parking barrier construction idea is shown, as well as the way to control the barrier and the way the barrier moves. Later, it is shown how the battery pack powered parking barrier works. Several tests have been performed on three different battery pack solutions, produced by different manufacturers, to show the durability and with that the quality of each of the battery packs. Data for each test is collected and analyzed.
\end{abstract}

Keywords: smart parking barrier; electric cylinder; controller; battery; voltage; energy consumption

\section{Introduction}

Nowadays, large traffic jams and waiting in cars on the way to work, theatres, cinemas and the places like that have become a daily routine in big cities as well as in smaller towns in the world. Drivers spent a lot of time searching for parking space when going to work, cultural or sporting events or in front of shops, and that became an unavoidable reality for many people around the world. One survey shows that during rush hour in most big cities, the traffic generated by cars searching for parking spaces takes up to $40 \%$ of the total traffic [1]. There are many different solutions to the problem discussed above, such as large organized parking with parking space occupancy monitoring and various solutions in form of a mobile app to help the user find free parking space in the shortest possible time. In addition to these solutions, one of advanced solution is to apply smart parking barriers for this purpose. The basic idea of the smart parking barrier is to create possibility for people to make a reservation of specific parking space with the mobile application on their smartphones. With these options, the users would be sure to have a free parking space on the desired location. This kind of smart parking barrier represents one Mechatronics system. Usually, Mechatronics is defined as an interdisciplinary field which includes mechanical engineering, electrical engineering, computer science and control engineering [2][3]. This way of reserving a free parking space by using modern technologies and internet infrastructure means that smart 
parking barrier belongs to a group of IoT (The Internet of Things) devices. The Internet of Things, meanwhile, refers to the connection of devices (other than the usual examples such as computers and smartphones) to the Internet [4]. After the arrival of the user in front of the smart parking barrier, with the help of the application and Bluetooth technology used for connecting to the barrier, the user will be able to lower down the barrier and park their vehicle. Due to its small size and low power consumption, as well as relatively high-speed data transfer, the Bluetooth is suitable for usage in mobile devices and mobile sensors [5]. This research paper presents a preliminary design of a smart parking barrier driven by an electric cylinder. The power supply to the smart parking barrier, or the cylinder as well as all the necessary components for its functioning, comes from the batteries supply. Using batteries as a power source gives it autonomy and easy installation. When the battery is discharged it can be easily replaced with a new one and the removed battery can be recharged and stored for later use.

\section{Proposed design of smart parking barrier}

This smart parking barrier is designed in such a way that it can be easily installed in existing parking spaces. In order to simplify the installation of the smart parking barrier, the barrier is designed in the form of a roller. During the installation process it is necessary to dig a hole of appropriate dimensions and place a smart parking barrier into that hole. Smart parking barrier is powered by a battery pack, so it's not necessary to bring in a power cable, which significantly reduces the time required and the labor involved in installation. The 3D model of the smart parking barrier is shown in Fig. 1. Parts of the smart parking barriers can be divided into two groups: movable and immovable parts. The group of fixed parts includes guides, a board located on the upper side of the smart parking barrier, which is connected to the base by screws and there is lower board which has a dual role. First role is to provide a support for the guides, and the second is to attach an electric cylinder to it. The moving part includes a piston that moves along the guides. At the center of the piston is an electric cylinder that drives the piston, then a controller needed to operate the cylinder, battery pack and other necessary electronics. At the top of the piston, a cover, with all the sensors and communication modules, required for the safe operation of the smart parking barrier, is located.

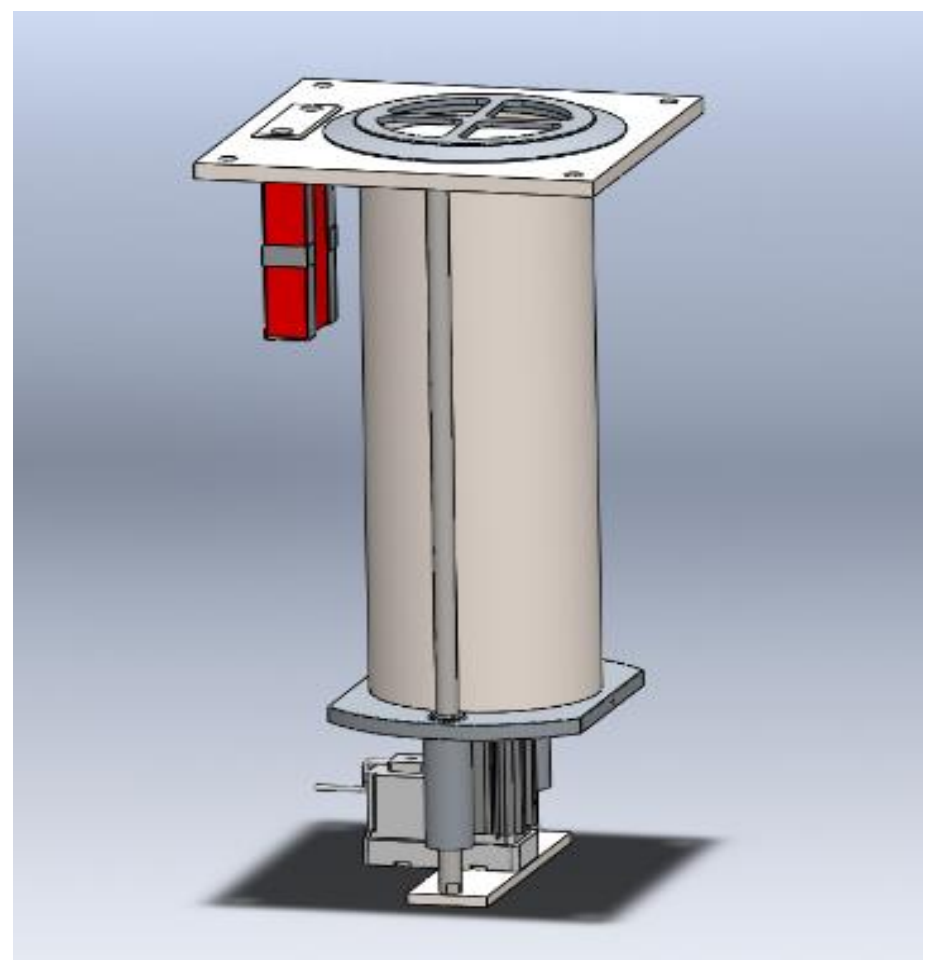

Fig. 1. 3D view of smart parking barrier

\section{Mechanical part of the smart parking barrier}

The smart parking barrier is driven by a linear cylinder of the LEY series, manufactured by SMC. The complete cylinder mark is LEY32C-500W-S16P1 shown in Fig. 2. In cylinder mark number 32 represents the diameter of the cylinder piston rod in $\mathrm{mm}, \mathrm{C}$ represents how long the cylinder stroke changes during one full engine revolution and it is $4 \mathrm{~mm}$. Number 500 represents the stroke of the cylinder, S represents that a standard cable is used for power and control, while 6P determines which controller can be operated by an electric cylinder [6]. 


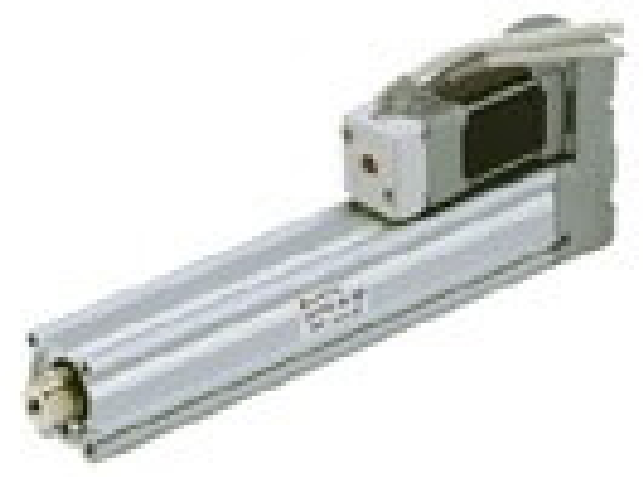

Fig. 2. The physical look of electric cylinder LEY32C-500W-S16P1 [6]

The linear motion of the piston rod is achieved by using a stepper motor. The step motor transforms the rotary motion into a linear through the pulley, belt and gear. The power to the motor is $24 \mathrm{~V} \mathrm{DC}$. The stroke of the cylinder is $500 \mathrm{~mm}$, the pushing force is in the range of 8 to $250 \mathrm{~mm} / \mathrm{s}$, while the acceleration and deceleration range from 0 to $3000 \mathrm{~mm} / \mathrm{s}$ [6]. The electric cylinder also has an electrical brake that can be activated when the cylinder is stationary. When the electric brake is activated, the cylinder can hold the load in a vertical position even though it was previously switched off. To establish the necessary movement of the smart parking barrier, the electrical cylinder is positioned in a vertical position. The cylinder piston rod is connected to the smart parking barrier cap, while the engine, end of the electric cylinder attached to the lower barrier board, thus allowing the smart parking barrier to function properly.

The electric cylinder is operated using a LECP6 series controller, which is also the same as the cylinder from the SMC manufacturer. The exact designation of the selected controller is LECP6P1-LEY32C-500 shown in Fig. 3. LEC in the designation indicates that it is a controller, $\mathrm{P}$ represents the type of motor that can be operated, in this case it is stepper motor, the number 6 indicates how many different positions we can achieve, and in this case, it is 64 different positions. $\mathrm{P}$ says that it is PNP type, number 1 indicates the cable cross-section, while the rest of the label indicates which electric cylinder can be operated [7].

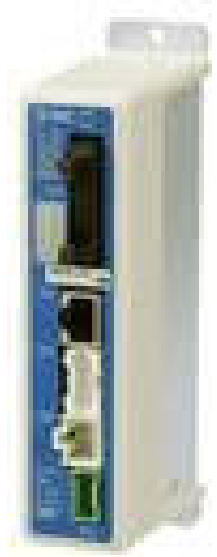

Fig. 3. The physical look of the controller [7]

The controller has 13 inputs and 13 outputs in total. Six input signals (IN0, IN1, IN2, IN3, IN4, IN5) are used to define 64 different positions of the electric cylinder, then there are also SETUP, HOLD, DRIVE, RESET, SVON, COM + and COM- signals. Output signals include 6 signals (OUT0, OUT1, OUT2, OUT3, OUT4, OUT5) that map the input signals after reaching the desired position. In addition to these signals, there are also BUSY, AREA, SETON, SETUP, INP, SVRE, ALARM signals [7]. Each position is set up using 12 parameters that define the movement to the desired position. Positions are defined in a suitable program called ACT Controller. After defining all the required positions, they must be loaded into the controller in order to achieve them. The parameters which define motion need to specify Move M, Speed, Position, Accel, Decel, PushingF, TriggerLV, PushingSp, MovingF, Area1, Area2 and In pos. 


\section{Power supply of smart parking barrier}

Smart parking barrier, i.e. the electric cylinder, controller and the all other components necessary for operation are supplied by a specially designed battery pack. This makes it much easier to set up a barrier without additional unnecessary parts such as air compressors or hydraulic pumps. The battery pack is consisted of lithium-ion battery cells connected to a unique structure. In order to test the longevity of battery packs, it was decided to use three different battery cells manufacturers. Samsung, LG and HighStar battery cells were tested. All battery cells have the same nominal voltage of $3.7 \mathrm{~V}$, but they have a different capacity level. In order to obtain the desired voltage of the battery pack, it was necessary to connect a more battery cells in serial and parallel connection. So, there are eighteen interconnected battery cells in each battery pack, such that three cells are connected in parallel and such six groups of parallel connections are further connected in series to achieve the required voltage to power the smart parking barrier. The previously explained method of connecting the battery cells to the pack is shown in Fig. 4.

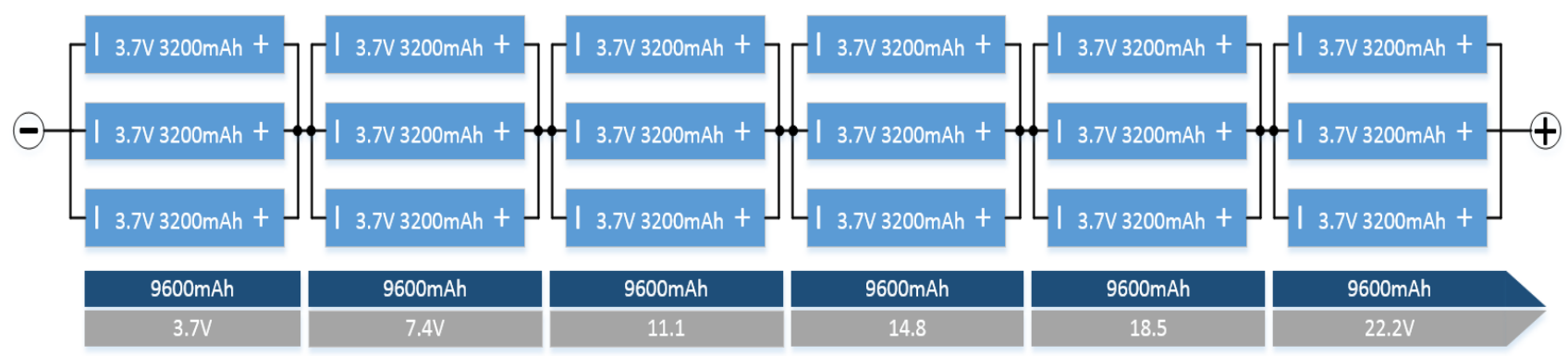

Fig. 4. Structure of battery cells inside the battery pack

In addition to the battery cells, the battery pack also includes a system called BMS (Battery Management System). The BMS balances the charge and discharge and also protects the pack from overloading and emptying. The following two tables shows the main characteristics of all battery cells and battery packs made of them.

\begin{tabular}{|c|c|c|c|c|c|c|c|c|}
\hline Battery cells & $\begin{array}{l}\text { Nominal } \\
\text { Voltage } \\
{[\mathrm{V}]}\end{array}$ & $\begin{array}{l}\text { Capacity } \\
{[\mathrm{mAh}]}\end{array}$ & $\begin{array}{l}\text { Max. } \\
\text { Charge } \\
\text { voltage } \\
{[\mathrm{V}]}\end{array}$ & $\begin{array}{l}\text { Max. } \\
\text { Charge } \\
\text { current } \\
{[\mathrm{mA}]}\end{array}$ & $\begin{array}{l}\text { Max. } \\
\text { continuous } \\
\text { discharge } \\
\text { current }[\mathrm{A}]\end{array}$ & $\begin{array}{l}\text { Discharge } \\
\text { Cut-off } \\
\text { Voltage } \\
{[\mathrm{V}]}\end{array}$ & $\begin{array}{l}\text { Temperature } \\
\text { range of } \\
\text { charge }\left[{ }^{\circ} \mathrm{C}\right]\end{array}$ & $\begin{array}{l}\text { Temperature } \\
\text { range of } \\
\text { discharge } \\
{\left[{ }^{\circ} \mathrm{C}\right]}\end{array}$ \\
\hline $\begin{array}{c}\text { HighStarISR186 } \\
\text { 50-2200 }\end{array}$ & 3.7 & 2200 & 4.2 & 1100 & 11 & 2.75 & $0 \sim 45$ & $-20 \sim 60$ \\
\hline $\begin{array}{c}\text { LG } \\
\text { INR18650 MH1 }\end{array}$ & 3.67 & 3200 & 4.2 & 1550 & 10 & 2.5 & $0 \sim 45$ & $-20 \sim 60$ \\
\hline $\begin{array}{c}\text { Samsung } \\
\text { INR18650-35E }\end{array}$ & 3.60 & 3500 & 4.2 & 1700 & 8 & 2.65 & $0 \sim 45$ & $-10 \sim 60$ \\
\hline
\end{tabular}

Table 1. Main characteristics of used battery cells [8][9][10]

\begin{tabular}{|c|c|c|c|c|}
\hline $\begin{array}{c}\text { Battery } \\
\text { packs }\end{array}$ & $\begin{array}{c}\text { Nominal } \\
\text { Voltage } \\
{[\mathrm{V}]}\end{array}$ & $\begin{array}{c}\text { Capacity } \\
{[\mathrm{mAh}]}\end{array}$ & $\begin{array}{c}\text { Max. Charge } \\
\text { voltage [V] }\end{array}$ & $\begin{array}{c}\text { Max. Charge } \\
\text { current [A] }\end{array}$ \\
\hline HighStar & 22.2 & 6600 & 25.2 & 1.1 \\
\hline LG & 22.2 & 9600 & 25.2 & 1.5 \\
\hline Samsung & 22.2 & 10500 & 25.2 & 1.7 \\
\hline
\end{tabular}

Table 2. Main characteristics of battery packs (authors calculation)

\section{Tests of battery packs}

In this paper two different types of tests are presented. The fist testes were directed at testing capacity of battery packs. This test measured the number of times a full smart parking barrier cycle could be done with each of the above battery packs. A full cycle of movement involves pulling out the smart parking barrier to its maximum limit and again pulling in. The second part of research focused on the consumption of electricity generated by smart parking barrier when lifting and lowering. 
In order to carry out the first part of the research, it was necessary to use a Voltage sensor, which measured the voltage of the battery packs. A Raspberry Pi 3 Model B microcontroller was also used, which was the control unit.

The Raspberry Pi controlled the movement of the smart parking barrier by sending commands to the controller of the electric cylinder, in addition to counting how many cycles were completed. During the test of the battery pack capacity, the lifting speed of smart parking barrier was set to $100 \mathrm{~mm} / \mathrm{s}$ and lowering speed to $150 \mathrm{~mm} / \mathrm{s}$, while the break between each new cycle was $500 \mathrm{~ms}$. Based on the number of completed cycles and the voltage of battery pack during each cycle, it is obvious on the graphs that voltage drops as the number of completed cycles increase. Each battery pack was conducted through test using same conditions.
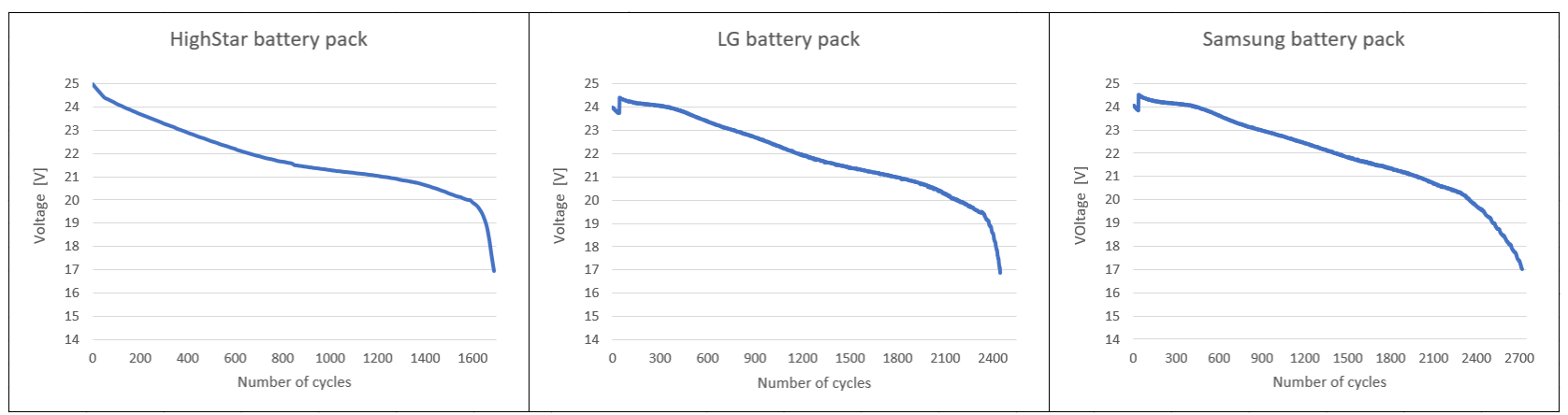

Fig. 5. Dependence of battery pack voltage drop on the number of smart parking barrier cycles completed (authors calculation)

Based on the results obtained, which are shown in Fig. 5. it can be concluded that the change in voltage during motion is similar for all tested batteries. The biggest differences are in the number of completed cycles, which is conditioned by different capacity of battery packs. The voltage drop is almost linear up to the limit voltage of the battery pack after which the voltage starts to drop dramatically. This voltage limit also varies with battery packs. Battery pack produced by HighStar has completed 1690 cycles. Another battery pack made by LG has completed 2446 cycles and Samsung battery packs has completed 2718 cycles. This difference in the completed cycles can be clearly seen in Fig. 6 . Results based on these tests, show the relation between the number of completed cycles and the battery capacity, where increase in battery capacity causes an increase in number of cycles.

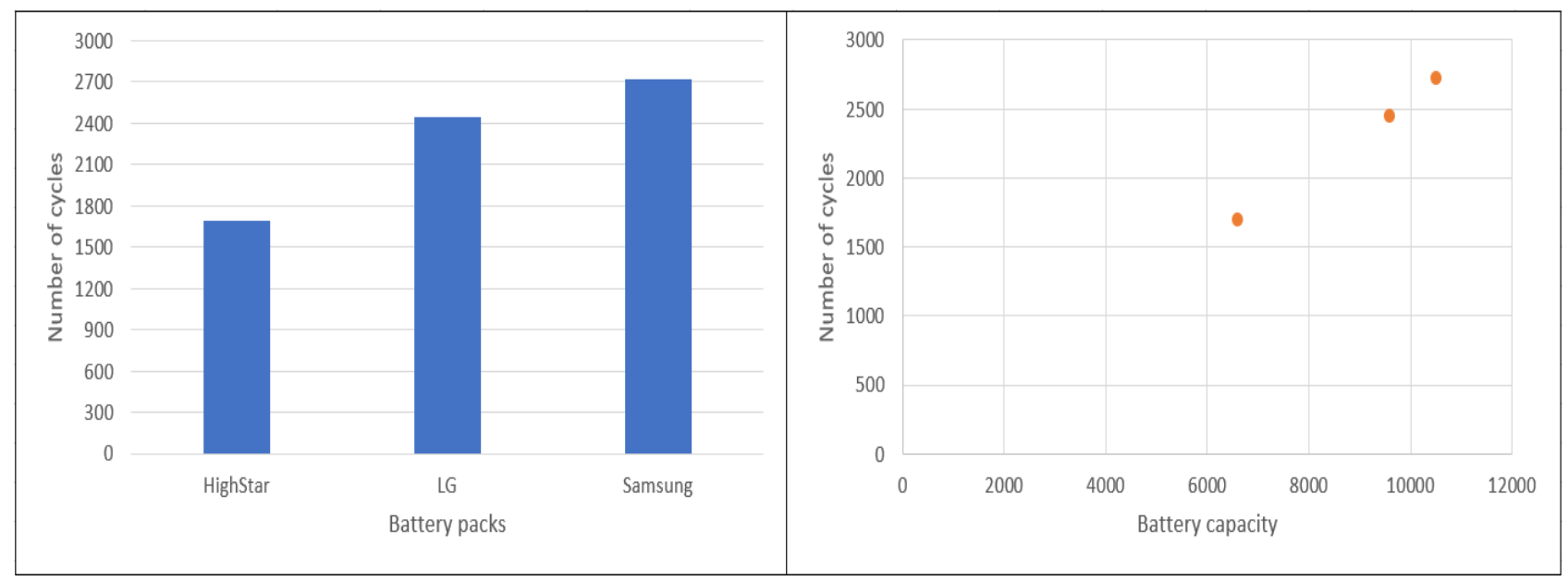

Fig. 6. Dependence of number of cycles on battery packs (author's calculation)

Fig. 7. Dependence of number of cycles on battery capacity (author's calculation)

The second part of the test aim to show the consumption of electrical current by smart parking barrier. In order to determine this parameter, it was necessary to use an oscilloscope and a shunt resistor. The oscilloscope probe is connected in parallel with the shunt resistor. In this way, the voltage drop on the shunt resistor is obtained on the oscilloscope and then the desired current consumption of the smart parking barrier is obtained by applying Om's law. The used shunt resistor has a resistance of $0.56 \Omega$ and a power of $5 \mathrm{~W}$. 


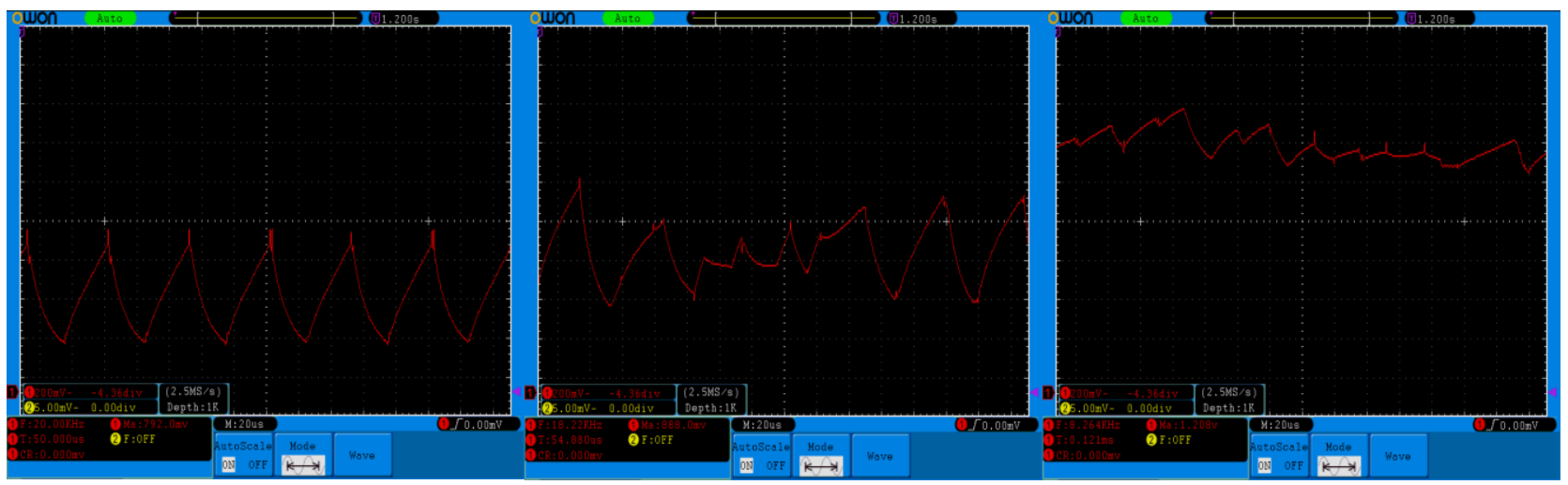

Fig. 8. Current consumption of the smart parking barrier during: standstill, lowering and rising (author's calculation)

The current consumption was measured in condition where the smart parking barrier was stationary and in motion. Figure 8. shows the results for previously mentioned cases. Every division on the oscilloscope displays a value of $200 \mathrm{mV}$. The zero line is located after the second division from the bottom of the screen. The voltage drops during action of standstill, lowering and raising of the smart parking barrier are: $600 \mathrm{mV}, 800 \mathrm{mV}$ and 1200mV. Applying Om's law on previous results, was obtained current consumption by smart parking barrier during action of standstill, lowering and raising are 1.07A, 1.43A and 2.14A. Based on the given results, we can conclude that the used battery cells enable proper functioning of smart parking barrier.

\section{Conclusion}

Following the urbanization tendency and increase of the population in cities, as well as an increase in the number of cars, problems with parking spaces will become more prominent, so we try to give some recommendation for its solving. These problems can be solved using advanced and smart technologies [11]-[15]. Smart parking barriers also have the potential to help solve this huge problem, by making it easier for users to find a free parking space. This product can be used for improvement of parking security and better parking control. With the support of the smart parking barrier it is possible to reduce the time required to find a parking space by reserving the space at the desired location. Reducing the time required to find free parking lot helps with reduced fuel consumption as well as lowering the negative impact on an environment. Smart parking barrier can be installed in residential buildings, commercial business parks, hotels, hospitals, airport, shopping malls, pedestrian zones, etc. Current detected problem is higher costs of implementation of this solution in comparison to conventional parking barriers. For now, this is the only solution for fully secured reservation of parking space implemented in a very simple way. Next step in parking barrier research and development can be improvement logical part of this complex system. It means advanced development of microcontroller software for better controlled manage of parking barrier and higher level of communication between parking barrier and users on one side, and parking barrier and server on the other. Creating a server for analyzing data related to user access rules, as well as creating a user application for smart phones, will also be an important task in the future.

\section{Acknowledgments}

This research has been supported by the Provincial Secretariat for Higher Education and Scientific Research of Autonomous Province of Vojvodina, Republic of Serbia, through the project: "Implementation of IoT tracking system for fresh food produces from Vojvodina", and Ministry of Education, Science and Technological Development, Government of the Republic of Serbia, through the projects: TR35001, III46001 and Grant 401-00-00589/2018-09.

\section{References}

[1] Paul, S. W. (2007). No vacancy: Park slope's parking problem, Transportation alternatives, http://www.transalt.org/newsroom/releases/126, Accessed: 2019-09-10.

[2] Stankovski, S.; Ostojic, G.; Zhang, X. (2016). Influence of Industrial Internet of Things on Mechatronics, Journal of Mechatronics, Automation and Identification Technology, Vol. 1, No.1, March 2016, pp. 1-6, ISSN $2466-3603$.

[3] Stankovski, S.; Ostojic, G.; Zhang, X.; Baranovski, I.; Tegeltija, S. \& Horvat, S. (2019). Mechatronics, Identification Technology, Industry 4.0 and Education, Proceedings of the 18th INFOTEH-JAHORINA 2019, Ljuboje Z. (Ed.), IEEE, East Sarajevo, Bosnia and Herzegovina, DOI: 10.1109/INFOTEH.2019.8717775.

[4] Markov, M.; Stankovski, S.; Ostojic, G., Baranovski, I. \& Horvat, S. (2018) Application of Firebase Cloud Service for Storing and Analyzing Data from IoT Mobile Devices, Vol. 3, No. 2, June 2018, pp. 1-6, ISSN 2466-3603. 
[5] Stankovski, S.; Ostojic, G.; Djukic, N.; Tegeltija, S. \& Milojkovic, A. (2014) Bluetooth parking access control, Sensor Review, Vol. 34, No. 3, 10 June 2014, pp. 244-254, ISSN: 0260-2288.

[6] SMC (2012). Operation manual, https://www.smc.eu/smc/Net/EMC_DDBB/op_manual/data/attachments/LEYOM002xx.pdf, Accessed: 2019-10-14.

[7] SMC (2018). Operation manual, https://www.smc.eu/smc/Net/EMC _DDBB lop_ manual/data/attachments/OM_LECP 6_OMT0011EN-A.pdf, Accessed: 2019-10-09.

[8] Agena (2016). Product $\quad$ specification, ns.co.rs/fileuploader/download/download/?d=1\&file=custom\%2Fupload\%2FFile-1499753795.pdf,Accessed: 2019-10-10.

[9] Agena (2014). Product specification, http://www.agenans.co.rs/fileuploader/download/download/?d=1\&file=custom\%2Fupload\%2FFile-1499250309.pdf,Accessed: 2019-10-10.

[10] Agena (2015). Specification of product, http://www.agenans.co.rs/fileuploader/download/download/?d=1\&file=custom\%2Fupload\%2FFile-1499250160.pdf,Accessed: 2019-10-10.

[11] Senk, I.; Ostojic, G.; Jovanovic, V.; Tarjan, L. \& Stankovski, S. (2015). Experiences in developing labs for a supervisory control and data acquisition course for undergraduate mechatronics education, Computer Applications in Engineering Education, Vol. 23, No. 1, January 2015, pp. 54-62, ISSN 1061-3773.

[12] Ostojic, G.; Stankovski, S.; Lazarevic, M. \& Jovanovic, V. (2007) Implementation of RFID technology in parking lot access control system, 1st Annual RFID Eurasia conference, 5-6 Sept. 2007, DOI: 10.1109/RFIDEURASIA.2007.4368095.

[13] Nemet, S.; Kukolj, D.; Ostojic, G.; Stankovski, S., \& Jovanovic, D. (2019). Aggregation framework for TSK fuzzy and association rules: interpretability improvement on a traffic accidents case. Applied Intelligence, pp. 1-14, ISSN: 0924-669X.

[14] Ostojic, G.; Stankovski, S.; Tejic, B.; Đukic, N.; Tegeltija, S. (2015). Design, control and application of quadcopter, InternationalJournal of Industrial Engineering and Management (IJIEM), Vol. 6 No 1, March 2015, pp. 43-48, ISSN 2217-2661.

[15] Vekic, A.; Borocki, J.; Stankovski, S. \& Ostojic, G. (2017) Development of innovation in field of precision agriculture, 2017, 28th DAAAM International Symposium on Intelligent Manufacturing and Automation, DAAAM 2017, Zadar, Croatia, 8 -11 November 2017, ISSN 1726-9679, Vienna, Austria, DOI: 10.2507/28th.daaam.proceedings. 111 . 